\title{
Two Decades of Reform: The Changing Organization Dynamics of Chinese Industrial Firms
}

\author{
Shahid Yusuf and Kaoru Nabeshima \\ Development Economics Research Group \\ The World Bank
}

\begin{abstract}
Since the early 1980s, China has begun gradually integrating with the global system. In doing so, the country has moved towards its own unique brand of market socialism, which recognizes private ownership, and is adopting market institutions and pursuing industrial change within the framework of an urban economic environment. The process of transition has now permeated every corner of Chinese life and no organization has been left untouched. Yet, industrial organization in China - especially in the state sector-has been slow to shed many of the distinctive structural characteristics of the old line Maoist era state enterprises. The main prong of the industrial strategy in support of urban change is ownership reform that transforms stateowned enterprises into corporate entities with majority state ownership or places them wholly in private hands. This strategy is bolstering the incentives for and the dynamism of the private sector. While the central government spearheads the ownership reform initiative, in the majority of cases the actual implementation is in the hands of municipal, county, and prefectural governments. This paper situates industrial change in China within the context of urban development and examines the interplay of broad reform strategy with local implementation, and its actual practice by the reformed firms.
\end{abstract}

JEL Code: P31; R11; O14; O31

Key words: China, urban economy, state-owned enterprise, reform

World Bank Policy Research Working Paper 3806, January 2006

The Policy Research Working Paper Series disseminates the findings of work in progress to encourage the exchange of ideas about development issues. An objective of the series is to get the findings out quickly, even if the presentations are less than fully polished. The papers carry the names of the authors and should be cited accordingly. The findings, interpretations, and conclusions expressed in this paper are entirely those of the authors. They do not necessarily represent the view of the World Bank, its Executive Directors, or the countries they represent. Policy Research Working Papers are available online at http://econ.worldbank.org.

The paper was prepared for the project on "Urban China in Transition" sponsored by the Urban China Network, SUNY Albany and was presented at a conference in New Orleans, January 1516, 2005. We greatly appreciate the constructive feedback from conference participants. Authors would like to thank, in particular, John Logan and Susan Fainstein for their helpful suggestions and Shiqing Xie for providing excellent research assistance. 


\section{Two Decades of Reform: The Changing Organization Dynamics of Chinese Industrial Firms \\ by Shahid Yusuf and Kaoru Nabeshima}

\section{Introduction}

China's adoption of the socialist model in the early 1950s and with it a largely autarchic approach to development resulted in an industrial structure and in industrial organizations quite different from those of more open, free market economies. The sub-sectoral mix favored heavy industry which was viewed as the backbone of the socialist economy. And the typical enterprise was on average smaller than its counterpart in a capitalist economy, vertically integrated, oriented towards a local or at best the provincial economy, administratively an extension of a supervisory industrial bureau, and tasked with providing social services to its workforce. Since the early 1980s, however, China has begun gradually integrating with the global system and in doing so it has moved towards its own unique brand of market socialism which recognizes private ownership, is adopting market institutions, and is pursing industrial change within the framework of an urban economic environment. The process of transition has already lasted a quarter century and it is far from over. It has now permeated every corner of Chinese life and no organization has been left untouched. Yet remarkably for an economy where the ratio of trade to GDP approaches 65\%, industrial organization in China—especially in the state sector—has been slow to shed many of the distinctive structural characteristics of the old line Maoist era state enterprises. Both state-owned enterprises (SOEs) as well as many of the non-state enterprises remain embedded in a web of formal and informal relationships that link producers to the administrative or financial organs of the state. Similarly, while the evidence of change in the urban sector is everywhere and is impinging on organization, notable also is the tenacity of 
institutions and administrative practices that emerged in the pre-reform era when the Chinese economy was on a different trajectory. China's level of urbanization, which is close to $40 \%$, is significantly below that of countries at comparable stages of development and of developed countries. ${ }^{1}$ Many cities continue to enforce hukou (residence) based restrictions on permanent migration and have only slowly started to dismantle the plethora of regulatory controls over every form of economic activity that were the hallmark of a communist society.

Chinese policymakers recognize that the urban sector can achieve a "balanced" development that holds poverty and inequality in check only if industrial reforms provide a sufficient growth impetus and jobs for the swelling workforce. ${ }^{2}$ The main prong of the industrial strategy in support of urban change is ownership reform that transforms SOEs into corporate entities with majority state ownership or places them wholly into private hands, in the process also bolstering the incentives for and the dynamism of the private sector. While the central government spearheads the ownership reform initiative in the majority of cases, the actual implementation is in the hands of municipal, county, and prefectural governments that must coordinate their efforts with other factors influencing urban changes. However, the ultimate success of the reforms rests substantially with the firms themselves, in particular, their managers and directors who must steer these enterprises through an environment that is increasingly competitive locally and integrating rapidly with the wider national and international economy.

\footnotetext{
${ }^{1}$ The reasons why the urbanization rate is low in China are the low fertility rate in urban areas because of the successful enforcement of one-child policy and the restriction on migration. For large cities such as Shanghai, the urban growth is almost entirely the result of the inflow of migrants (see Liang, Luong, and Chen 2005).

${ }^{2}$ So far the Chinese government was able to reduce the number of absolute poor in the urban areas, an impressive achievement compared to the experience elsewhere. However, inequality within the urban area is rising (see Appleton and Song 2005).
} 
In a word, the purpose of this paper is to situate industrial change within the context of urban development and to examine the interplay of broad reform strategy with local implementation, and its actual practice by the reformed firms themselves.

\section{Industrial Development: The Early Years}

Industrialization has been the leitmotif of China's development since the mid 1950s. During the early stages, starting with the First Five Year Plan in 1950, the government's emphasis was on establishing state ownership and building heavy industry, following the lead of and material support from the USSR, and with guidance from Soviet advisers who helped China lay the foundation of a planned socialist economy. ${ }^{3}$ By the mid 1960s, a broad-based industrial system was emerging in China's traditional urban industrial heartland in Manchuria, in the Shanghai area and a few inland cities such as Wuhan (Andors 1977). At that time, little more than 15 percent of the population lived in the urban areas and the principal industrial cities dominated the urban landscape. Industry accounted for close to 50 percent of China's GDP with over half of this produced by heavy industries centered on ferrous metal manufacturing and machinery producers. The microstructure of the industrial system was comprised of enterprises subject to plans that set production targets and allocated commensurate volumes of inputs to each of the producers (Chow 1985). In effect, the manufacturing enterprise was no more than an extension of the bureaucratic apparatus—central and subnational—for controlling the economy. ${ }^{4}$ It had limited management capacity and management in turn had limited discretion (Richman 1969). The urban industrial labor force, while paid modest wages, was a highly privileged group because it enjoyed lifetime tenure and schooling, health, pension, and other benefits that set it

\footnotetext{
${ }^{3}$ Close to 45\% of China's imports during 1950-1961 were from the USSR (Riskin 1987). See also Wheelwright and McFarlane (1970).

${ }^{4}$ In keeping with their lowly status, enterprises were called gongfang or factories.
} 
apart from the rest of the workforce. These privileges were sustained by strictly limiting migration to the cities by instituting a household registration system (hukou) in the late 1950s (see, for instance, Fan 2004).

In the latter half of the 1960s, when the Cultural Revolution was in full swing, the Third Front program dispersed industries from the urban centers in the East and Northeast to the interior provinces, especially the southwestern region, to increase their survival chances in the event of war and to plant the seeds of industrial capability throughout the country (Naughton 1988). This was followed by efforts to build small scale rural industries, and some decentralization of economic decision making to provincial or county level agencies (Riskin 1987). However, on the eve of the reform era towards the end of the 1970s, the organization of production and the working of enterprises still conformed closely to the model instituted two decades earlier. In particular, the large sized enterprises responsible for the lion's share of manufactured products remained under the tight control of central and provincial bureaus.

The backwardness of China's industries relative to some of its East Asian neighbors, the inefficiencies of the centrally planned economy, agricultural stagnation, and the urgent need to accelerate growth and provide jobs that would reverse the spread of poverty empowered the reformers among the senior members of the Communist Party. Their initial proposals announced at the $3^{\text {rd }}$ Plenum of the $11^{\text {th }}$ Central Committee in 1978 have bit by bit transformed China's command economy (Riskin 1987) into a decentralized, socialist market economy with institutions and ownership rights that are coming to resemble those of the capitalist economies in East Asia and elsewhere. This process of institutional change has been a slow one. It has been interspersed with much experimentation through which reform ideas were subjected to trials on a limited scale before being adopted more widely. And throughout the past 25 years, each 
tentative reform has been preceded by often intense debate and political dueling among reformers of all stripes, as well as between the reformers on the one hand and more orthodox elements in the Party opposed to the progressive dismantling of socialism in China on the other.

Although early reforms mainly affected the agriculture sector where dissatisfaction with communist institutions was most pronounced, ${ }^{5}$ arguably the most far reaching reforms have impinged on industrial enterprises in the urban areas, particularly those in the coastal provinces. In the first half of the 1980s, the dramatic improvement in agricultural performance became the principal determinant of growth in GDP. Thereafter, regionally targeted policies ensured that growth was largely driven by the increase in industrial output and productivity (see Table 1) with industries located in cities along the Eastern coast contributing a disproportionately large share. And the competitiveness of these industries depends not just on reforms introduced by the center but on the efforts of the municipal authorities themselves to improve the municipal business environment, as well as on the readiness of firms to grasp market opportunities.

Table 1: Contribution to GDP Growth by Sector

\begin{tabular}{|c|c|}
\hline & $\begin{array}{lllll}1980- & 1985-1990- & 1995- & \\
84 & 89 & 94 & 99 & 2000\end{array}$ \\
\hline Agriculture & 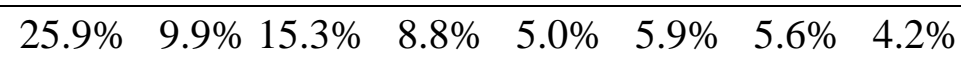 \\
\hline Industry & $43.5 \%$ 51.8\% 59.2\% 60.6\% 60.4\% 56.0\% 62.8\% 63.9\% \\
\hline Of which Manufacturing & $33.2 \%$ 42.4\% 39.5\% 39.2\% 47.0\% 39.4\% 44.9\% 53.6\% \\
\hline Services & $30.6 \%$ 38.4\% 25.5\% 30.6\% 34.6\% 38.1\% 31.6\% 31.9\% \\
\hline
\end{tabular}

Source: Author calculation using data from WDI

\footnotetext{
${ }^{5}$ The commune system inflicted great hardship especially in the less fertile areas of the country. By the late 1970s, the strength of grass roots opposition forced a loosening of the commune imposed restraints in Anhui and Sichuan. In Anhui, the first steps from the team-based system back to household farming in the Fengyang region were supported by Party Secretary Wan Li. Zhao Ziyang backed similar moves to the household responsibility system in Sichuan (Hutchings 2001; Perkins and Yusuf 1984).
} 


\section{Medium and Large State-owned Enterprises and Organizational Change}

The population of firms in China is vast and the diversity of organizational forms is on the rise. Not only are there SOEs, cooperatives, collectives and township and village enterprises (TVEs), to these have been added joint ventures (JVs) of many different kinds, wholly owned foreign subsidiaries and growing numbers of privately owned firms, following a constitutional amendment in 1988 legalizing individual ownership. Such proliferation makes it difficult to neatly trace the effects of reform or to typify organizational change. For this reason, we have chosen to examine one class of enterprises, the medium and large sized state-owned enterprise (MLSOEs). In addition, our attention is mainly focused on the major coastal cities where urban and organizational changes are in full swing and which stand at the apex of China's urban hierarchy.

There are advantages of such a selectivity as well as drawbacks but the former, we will argue, outweigh the latter. Among the advantages first of all is the weight of the MLSOEs in the urban industrial economy. The total of some 7,500 enterprises are responsible for close to a fifth of industrial GDP and this share has shrunk relatively little over the past decade even though the overall share of SOEs output has declined from 55\% in 1990 to $24 \%$ in 2002 as a result of the privatization or shuttering of tens of thousands of small SOEs and because of the rapid output growth registered by a variety of non-state firms. Moreover, MLSOEs are the source of $40 \%$ of China's exports and they account for nearly two-thirds of China's industrial fixed assets. A second consideration is the availability of information and detailed research on some of the leading MLSOE companies such as Baoshan Iron and Steel, CIMC, Lenovo, TCL International Holdings, and Kelon (see Table 2). The research is especially valuable because it adds depth and nuance to the dry statistics on the state sector. Third, the MLSOEs provide employment to a 
sizable segment of the urban workforce and these firms still shoulder substantial social obligations to the remnants of their core tenured workforce. Although the urban social safety net is no longer a responsibility of the state enterprise sector, the residual role of state firms is by no means trivial.

Fourth, because the MLSOEs include firms with some of the most advanced manufacturing and technological capabilities, as well as ties with the regulatory agencies, they have attracted the attention of foreign multinational corporations (MNCs) seeking local partners in order to enter and navigate successfully in the Chinese market. Hence, foreign direct investment (FDI) has flowed into China’s cities and many MLSOEs have entered into joint ventures with foreign investors which in turn has led to assimilation of hard and soft technologies by Chinese enterprises.

Fifth, since 1997, the authorities have moved aggressively to reform the ownership structure of MLSOEs and to privatize, divest or close the smaller SOEs. ${ }^{6}$ By introducing new governance and management practices, ownership changes are reinforcing pressures exerted by market competition on the state enterprise sector. Thus, the large economic and social roles of MLSOEs in the urban economy and their exposure to the global environment, to FDI, to new technologies and to reforms, make them a natural focus for research.

\footnotetext{
${ }^{6}$ Approximately 120,000 of the smaller SOEs have been divested.
} 
Table 2: Top 30 Selected Major Manufacturing Companies in China

\begin{tabular}{|c|c|c|c|c|c|c|c|c|c|}
\hline $\begin{array}{l}\text { Rank } \\
2003\end{array}$ & $\begin{array}{l}\text { Rank } \\
2002\end{array}$ & Company & Major Products & Revenues & Profits & $\begin{array}{l}\text { Profits as } \\
\text { \% Revenue }\end{array}$ & Market ValueF & $\begin{array}{l}\text { as } \% \\
\text { et Value }\end{array}$ & $\begin{array}{l}\text { Controlling } \\
\text { Ownership }\end{array}$ \\
\hline$\overline{6}$ & 5 & Baoshan Iron \& Steel & Iron and steel & $\$ 4,092.70$ & $\$ 516.10$ & $12.61 \%$ & $\$ 6,227.70$ & $8.29 \%$ & State $^{\mathrm{b}}$ \\
\hline 13 & 6 & Legend Group & Computers & $\$ 2,593.30$ & $\$ 133.80$ & $5.16 \%$ & $\$ 2,490.90$ & $5.37 \%$ & State \\
\hline 21 & 22 & TCL International Holdings & Home appliances & $\$ 1,562.40$ & $\$ 78.00$ & $4.99 \%$ & $\$ 806.60$ & $9.67 \%$ & State \\
\hline 22 & 24 & Sichuan Changhong Electric & Home appliances & $\$ 1,520.40$ & $\$ 21.30$ & $1.40 \%$ & $\$ 1,759.60$ & $1.21 \%$ & State \\
\hline 23 & 18 & Beijing Shougang & Iron and steel & $\$ 1,519.90$ & $\$ 82.50$ & $5.43 \%$ & $\$ 1,593.50$ & $5.18 \%$ & State \\
\hline 27 & 20 & Qingdao Haier Holdings & Home appliances & $\$ 1,395.80$ & $\$ 48.00$ & $3.44 \%$ & $\$ 895.20$ & $5.36 \%$ & Collective \\
\hline 30 & 21 & Guangdong Midea Holding & Home appliances & $\$ 1,312.90$ & $\$ 18.70$ & $1.42 \%$ & $\$ 402.40$ & $4.65 \%$ & State \\
\hline 31 & 25 & Angang New Steel & $\begin{array}{l}\text { Metal fabrication and } \\
\text { hardware }\end{array}$ & $\$ 1,301.30$ & $\$ 71.80$ & $5.52 \%$ & $\$ 910.90$ & $7.88 \%$ & State \\
\hline 33 & 36 & Chongqing Changan Automobile & Auto manufacturing & $\$ 1,194.10$ & $\$ 100.90$ & $8.45 \%$ & $\$ 1,013.00$ & $9.96 \%$ & State \\
\hline 37 & 43 & $\begin{array}{l}\text { China International Marine Containers } \\
\text { Group }\end{array}$ & $\begin{array}{l}\text { Packaging and } \\
\text { containers }\end{array}$ & $\$ 1,096.80$ & $\$ 56.20$ & $5.12 \%$ & $\$ 5,304.80$ & $1.06 \%$ & State \\
\hline 39 & 28 & Jinzhou Petrochemical & Chemicals & $\$ 1,091.10$ & $\$ 1.50$ & $0.14 \%$ & $\$ 479.50$ & $0.31 \%$ & State \\
\hline 40 & 57 & Great Wall Technology & Computers & $\$ 1,056.20$ & $\$ 8.40$ & $0.80 \%$ & $\$ 47.70$ & $17.61 \%$ & Foreign \\
\hline 41 & - & TCL Communications Equipment & Home appliances & $\$ 1,053.80$ & $\$ 33.40$ & $3.17 \%$ & $\$ 318.40$ & $10.49 \%$ & State \\
\hline 47 & 44 & Konka Group & Home appliances & $\$ 971.50$ & $\$ 4.30$ & $0.44 \%$ & $\$ 428.50$ & $1.00 \%$ & Private \\
\hline 55 & 79 & Beiqi Futian Vehicle & Auto manufacturing & $\$ 915.70$ & $\$ 15.30$ & $1.67 \%$ & $\$ 316.50$ & $4.83 \%$ & State \\
\hline 57 & 53 & Brilliance China Automotive Holdings & Auto manufacturing & $\$ 884.30$ & $\$ 91.70$ & $10.37 \%$ & $\$ 628.90$ & $14.58 \%$ & State \\
\hline 62 & 46 & Gree Electric Appliances of Zhuhai & Home appliances & $\$ 849.30$ & $\$ 35.90$ & $4.23 \%$ & $\$ 541.00$ & $6.64 \%$ & Collective \\
\hline 64 & 75 & Dongfeng Automobile & Auto parts and equipment & $\$ 845.70$ & $\$ 74.50$ & $8.81 \%$ & $\$ 1,824.20$ & $4.08 \%$ & State \\
\hline 65 & 63 & Tsingtao Brewery & Beverages & $\$ 838.00$ & $\$ 27.90$ & $3.33 \%$ & $\$ 784.50$ & $3.56 \%$ & State \\
\hline 66 & 51 & Wuhan Steel Processing & Iron and steel & $\$ 816.50$ & $\$ 7.80$ & $0.96 \%$ & $\$ 506.00$ & $1.54 \%$ & State \\
\hline 72 & - & Ningbo Bird & Diversified holdings & $\$ 769.30$ & $\$ 26.10$ & $3.39 \%$ & $\$ 391.80$ & $6.66 \%$ & Joint-Venture \\
\hline 73 & 85 & Shenzhen Kaifa Technology & Computers & $\$ 746.50$ & $\$ 7.30$ & $0.98 \%$ & $\$ 897.00$ & $0.81 \%$ & Joint-Venture \\
\hline 77 & 88 & Hisense Electric & Home appliances & $\$ 679.40$ & $\$ 4.20$ & $0.62 \%$ & $\$ 385.40$ & $1.09 \%$ & State \\
\hline 80 & 69 & Tsinghua Tongfang & Computers & $\$ 657.20$ & $\$ 22.20$ & $3.38 \%$ & $\$ 758.20$ & $2.93 \%$ & State \\
\hline 86 & 73 & Guangdong Kelon Electrical Holdings & Home appliances & $\$ 589.30$ & $\$ 12.20$ & $2.07 \%$ & $\$ 5,518.70$ & $0.22 \%$ & Collective \\
\hline 89 & 92 & Shanghai Automotive & Auto parts and equipment & $\$ 576.20$ & $\$ 129.30$ & $22.44 \%$ & $\$ 2,085.40$ & $6.20 \%$ & State \\
\hline 91 & 97 & FAW Car & Auto manufacturing & $\$ 574.50$ & $\$ 29.90$ & $5.20 \%$ & $\$ 1,166.00$ & $2.56 \%$ & State \\
\hline 93 & 80 & SVA Electron & Electronics & $\$ 562.50$ & $\$ 12.60$ & $2.24 \%$ & $\$ 2,054.40$ & $0.61 \%$ & Joint-Venture \\
\hline 96 & 93 & Shanghai Founder Yanzhong Sci. & Computers & $\$ 545.20$ & $\$ 15.60$ & $2.86 \%$ & $\$ 364.80$ & $4.28 \%$ & State \\
\hline 97 & - & Amoisonic Electronics & Electronics & $\$ 542.00$ & $\$ 73.30$ & $13.52 \%$ & $\$ 584.20$ & $12.55 \%$ & Joint-Venture \\
\hline
\end{tabular}

a. Controlling ownership is based on a phone inquiry into China Enterprises Confederation and online research.

b. State-owned enterprises include enterprises with controlling shares hold by the state.

c. Joint-Venture enterprises may also include enterprises with shares by state or collective or private. 
Although urban concentration in China is well below that of comparative countries and the world average - the Gini coefficient is 0.43 against 0.56 for the world in 2000 (see Table 3) (Henderson 2004) - just 10 major municipalities account for almost a quarter of China’s GDP and possibly a third of its growth rate (see Table 4). It is in these urban crucibles that China's new industrial economy is being nurtured.

Table 3: Urban Gini Coefficients of Selected Countries Brazil Japan Indonesia UK Mexico Nigeria France India Germany USA Spain

\begin{tabular}{lllllllllll}
\hline 0.65 & 0.65 & 0.61 & 0.60 & 0.60 & 0.60 & 0.59 & 0.58 & 0.56 & 0.54 & 0.52 \\
\hline
\end{tabular}

Source: Henderson (2004)

Table 4: Large cities' share of GDP

\begin{tabular}{ccc} 
Rank by GDP & City & Share of city GDP to national (\%) \\
\hline 1 & Shanghai & $5.2 \%$ \\
2 & Beijing & $3.1 \%$ \\
3 & Guangzhou & $2.9 \%$ \\
4 & Shenzhen & $2.2 \%$ \\
5 & Tianjin & $2.0 \%$ \\
6 & Chongqing & $1.9 \%$ \\
7 & Hangzhou & $1.7 \%$ \\
8 & Chengdu & $1.6 \%$ \\
9 & Qingdao & $1.4 \%$ \\
10 & Ningbo & $1.4 \%$ \\
\hline
\end{tabular}

Source: China Statistical Yearbook (2003)

However, the perspectives we gain from analyzing organizational changes in the urban context must be tempered by four considerations.

First, the MLSOEs in the major East Coast cities are losing ground to other firms and in certain subsectors are not the dynamic leading edge of the industrial economy. Many of the privately owned, foreign owned or joint venture firms are growing more rapidly and are aggressively experimenting with organizational as well as other innovations. Indeed, it can be 
argued that such firms might serve as more reliable guides as to what the future holds. But at this stage the stock of knowledge on these entities is relatively scant. Until such time as more information is forthcoming, we have to rely on research done on the larger SOEs.

A second reason for reflecting on the representativeness of the MLSOEs is their remaining social responsibilities to their workers. These tend to vary across enterprises, provinces, and municipalities and are poorly documented. What is becoming clearer is that the share of the tenured workforce has been declining and that of contract workers, with few-or-nosocial benefits from the enterprise has risen. In addition, municipal and other sub-national authorities are now shouldering many more of the safety net burdens thereby enabling MLSOEs to operate more like private and foreign owned firms. These trends are blurring but by no means erasing the distinctiveness of the SOEs.

The MLSOEs' access to financial resources through the mediation of local authorities or supervisory bureaus is a third factor that differentiates them from other firms. While there is little doubt that the budget constraint on MLSOEs is much harder than in the past with far less fiscal support forthcoming from the national government or subnational sources, it remains true that, MLSOEs absorb a disproportionate amount of credit ${ }^{7}$ and the supply of such funding at state set rates privileges them over private firms. Moreover, the softer budget constraint ${ }^{8}$ can influence strategy, management, and efficiency often in deleterious ways.

Lastly, the close past ties of MLSOEs with supervisory bureaus, which defined in varying degrees of detail the parameters governing enterprise objectives and operations and shaped the internal organization, incentives and autonomy, are certainly unraveling but it is unclear how far

\footnotetext{
${ }^{7}$ Although MLSOEs may be more creditworthy because of their size and debt structure, they now account for $20 \%$ of industrial outputs, yet claim approximately $60 \%$ of bank credit is funneled to SOEs (Honohan 2004).

${ }^{8} \mathrm{~A}$ firm is subject to a soft budget constraint when the state or the banking sector are willing to bail it out of difficulties fairly routinely. It is referring to an institutionalized weakness of financial discipline.
} 
the process has gone. In some cases, the supervisory bureaus were transformed into holding companies, orchestrating the activities of large enterprise groups with only modest changes occurring in the relationships between the two entities. In other words, state enterprises are at different stages of evolution, some are coming to resemble market-oriented firms, others are still no better than production units controlled by national or subnational industrial bureaus. The median MLSOE is, therefore, somewhat elusive and questions can be raised as to whether such an enterprise could be classified as typical of the newer breed of medium-sized enterprises in China.

In defense, we can claim that the MLSOEs are still prominent on China's industrial landscape and dominate a number of subsectors, for example, the consumer electronics, machinery, metallurgical and transport industries. Moreover, corporatization and joint ventures are giving these firms more leeway to set their course and once privatized, many are likely to remain among China's leading firms and several such as are already setting the pace and exerting a strong demonstration effect and are among the role models for other Chinese firms. What makes these firms especially interesting is their ongoing effort to arrive at organizational forms and modes of operation that viably fuse elements of legacy systems with other elements borrowed from East Asian and Western corporate models. All this is occurring in an urban environment in which control exercised by municipal or other agencies of the state is still pervasive and instigates, guides, modulates or obstructs corporate experimentation as MLSOEs venture deeper into the market economy and are exposed to the pressures of globalization.

Our reservations regarding the MLSOEs do not extend to the focus on the leading coastal cities. Trends that have surfaced in China during the past decade and international experience 
both suggest that urban development will be increasingly concentrated in large agglomerations along the East coast.

\section{Reforming China's Industry}

China's industrial enterprises in 1980 were the production units in a centralized command economy. The organizational structure of the typical MLSOE was relatively flat. Production, input supplies and interfirm transactions were regulated by the plan and implemented by the industrial bureaus. Managers enjoyed limited discretion —-their job was to ensure that production targets were met—and because all wages were fixed, there were few rewards for initiative at any level in the enterprise. Goods produced were distributed through state created channels as there were no markets to speak of. Transactions among firms were settled through a mono-banking system ${ }^{9}$ and the enterprise was permitted to hold only miniscule cash balances. In effect the purpose of enterprises was to manufacture and to care for their workers from the time they were recruited till the end of their lives. These tenurial and social security arrangements were costly for the state and they generated a bias towards capital intensive industries and production processes (Putterman and Dong 2000).

Initially the winds of reform blew mainly through the agriculture sector and left the SOEs largely untouched. However, by the latter half of the 1980s, a few isolated experiments launched in 1981-82 began to coalesce into a full fledged reform of the industrial sector. These enterprise reforms were reinforced by fiscal decentralization introduced in $1985 .{ }^{10}$ The reforms sought to enhance the performance of SOEs by giving them some autonomy to produce for newly expanded markets and permitting the deployment of contract-based incentive schemes for

\footnotetext{
${ }^{9}$ This was finally dismantled in 1984 with the creation of the PBC and four major state owned banks.

${ }^{10}$ Fiscal experiments that commenced in 1977 led to revenue sharing arrangements enacted in 1980 and to major reforms in 1985 that made sharing of revenues, mainly collected by subnational governments, the center piece of the fiscal system (Lin and Liu 2000).
} 
enterprise managers and their workforce. By devolving fiscal responsibilities to sub-national entities, they also encouraged municipal, county, and township governments to act entrepreneurially and promote non-state enterprises that would generate revenues and provide jobs. ${ }^{11}$ With sub-national, and particularly municipal authorities taking the lead, the incremental elaboration of enterprise and associated price and market reforms continued through the mid 1990s with some improvement in the productivity and profitability of SOEs. The non-state sector benefited even more. Its share of industrial output rose from 24\% in 1980 to 66\% in 1995 while that of the state sector fell to 34\% by 1995 .

From the standpoint of the MLSOEs, reforms in four areas were of vital significance. ${ }^{12}$ First, the creation of markets and freeing of many hitherto controlled prices opened a vast range of opportunities for producers and consumers. Starting with a limited range of foodstuffs and consumer items, the scope of free markets was expanded in steps to embrace many more products, components, equipment and raw materials. By the early 1990s, most consumer goods were being distributed through market channels leaving only 89 industrial goods and transport prices set by the state. Prices of 600 industrial producer goods had been decontrolled (Lardy 2002).

In parallel with the freeing of markets, a second set of reforms progressively opened the economy to trade, starting initially with producers in four special economic zones (SEZs): Shenzen, Zhuhai, Shantou, and Xiamen which quickly attracted investment from Hong Kong. ${ }^{13}$ Chinese enterprises were encouraged to export so as to enlarge the flow of urgently needed foreign exchange. Gradually these narrow windows were widened and in addition to the state trading corporations, more and more enterprises were given permission to trade (Lardy 1992).

\footnotetext{
${ }^{11}$ For differing perspectives on local initiatives, see Oi (1999), Duckett (1998), and Gore (1998).

12 On reforms through the early 1990s see Naughton (1996).

${ }^{13}$ See Howell (1993) and Wu (1999) on the creation of the early SEZs and the widening of trade channels.
} 
Over time also the mercantilist focus on exports - together with the import of material to be processed—gave way to more balanced policies that liberalized imports and pari passu, reduced tariff as well as non-tariff barriers.

A third and related reform, which coincided with the establishing of the four SEZs in Guangdong and Fujian provinces and the efforts to develop export-oriented industries, was the proffering of incentives to foreign investors at first in export oriented industries. By the mid 1990s, FDI was being welcomed into a much broader range of sectors including and in particular, commercial real estate and infrastructure. A trickle of FDI in the 1980s grew rapidly after 1993 and swelled to a flood in the late 1990s and China now ranks as the second largest recipient in the world after the U.S. The Pearl River Delta alone received 24\% of FDI.

The gradual integration of the domestic market with the dismantling of many barriers to trade was a fourth reform initiative. This built upon the increasing scope given to market transactions as well as investments by central and sub-national governments in transport and distribution infrastructure.

Together, these four reforms opened new vistas for China's urban economies. FDI became a conduit, mainly by way of joint ventures, for capital, skills and technology transfers. International trade, a more integrated domestic market, and the emergence of the non-state sector, exposed the SOEs to much needed competitive pressures, in some cases spurring them to adapt so as to make the most of opportunities now within their reach. ${ }^{14}$ Other reforms, many introduced by the major coastal municipalities, further stimulated market development, openness and access to FDI. Starting in the mid 1980s, the Chinese authorities began modifying the governance structure of SOEs and their relations with supervisory organs. Municipalities such as

\footnotetext{
${ }^{14}$ Such competition also eroded profit margins and tax revenues transferred to various levels of governments. The result was a sharp drop in the tax/GDP ratio, now gradually being reversed through a broadening of the tax base.
} 
Shenzhen, Guangzhou, Dongguan, Foshan, and Xiamen located in Guangdong and Fujian provinces led the way. The purpose was to give enterprises further autonomy and incentives to exploit market opportunities and in the process, to raise often deplorably low levels of efficiency. Management contracts and later, leasing of businesses, bonus schemes for production in excess of targets, greater freedom to determine the product mix, some latitude to adjust the labor force, permission to borrow from banks and implement investment plans, and less oversight by supervisory agencies, were some of the steps taken to motivate the SOEs and make them more responsive to market opportunities.

These measures began devolving responsibilities on the SOE and pushing it in the direction of acquiring the organizational capabilities of a firm and away from the status of a simple production unit which also served as a link in the urban social security system. From the early 1990s, the authorities began to form enterprise groups modeled on the lines of Japanese keiretsu so as to take advantage of scale economies and the benefits of lower transaction costs from intra-group trading and capital markets. ${ }^{15}$ By yoking together profitable and struggling enterprises, central and sub-national governments frequently attempted to revive or sustain loss making firms. One important consequence of the reforms was to reduce the scope of planning by state agencies and micro-level controls over enterprises were both reduced although the process was far from even. At the formal level, planned production targets were attenuated, without the command system being dismantled or the autonomy of enterprises being formally specified in a way that established legal rights. However, the flexibility introduced made it possible for provincial and county level officials—and enterprise managers— to take initiatives. A form of state corporatism began taking root with bureaucrat entrepreneurs essentially

\footnotetext{
${ }^{15}$ Many of these groups were created out of enterprises affiliated with an industrial bureau. Many industrializing economies have sought to use the creation of enterprise groups as a means of overcoming institutional gaps or missing market. See Yifei (2004) for a review of some of the presumed advantages of groups.
} 
commandeering state-owned industrial assets and exploiting the new freedoms afforded to enterprises to redirect their operations (Gore 1998). In many instances, these enhanced the productivity and profitability of enterprises, but just as often, the autonomy for managers and the loosening of rules governing the activities of industrial bureaus led to asset stripping (as was commonplace in other transition economies) or plunged enterprises into deeper losses. ${ }^{16}$

By the mid 1990s it was becoming clearer that a rolling back of the planning system without a dismantling of the national and subnational industrial bureaucracies that supervised the enterprises was leading to dysfunctional consequences. Bureaucratic accountability was fast disappearing and the governance of enterprises by the state was becoming haphazard and often distorted because of the leeway afforded by the reforms to bureaucrat entrepreneurs and ambitious enterprise managers.

To correct the problem associated with the first round of enterprise reforms, the state launched an ambitious reform drive starting in 1997. By then it was coming to be recognized that unless ownership rights were properly delineated and enforced, and unless the incentives for managers as well as all other employees were fully aligned with the market, the majority of state enterprises would struggle to achieve efficiency and profitability. The governance exercised by industrial bureaus or enterprise groups that took over some of the functions of bureau was inadequate and needed to be supplemented, or displaced, by market mechanisms. A privatization of state owned industrial enterprises seemed the logical course to take but instead a typically Chinese partial reform was brokered. This reform privatized thousands of the small scale enterprises, and loss making ones for which no buyers could be found were closed. However, MLSOEs accounting for most of the output of the state industrial sector were either left

\footnotetext{
${ }^{16}$ In many instances, mergers not only failed to turnaround loss makers, they also compromised the performance of their profitable partners.
} 
untouched or converted into limited liability shareholding firms in which the state continues to own the majority of shares and/or to exercise control rights. Thus there are now effectively two classes of state firms: those with some outside shareholders and others that remain pure SOEs. In theory, the former are closer to the threshold of the market system and are subject to governance from supervisory boards or boards of directors and hence more likely to be accountable to shareholders, to maximize shareholder value, and therefore, to take their cues from the market with respect to management, structure, strategy, and technology. In practice, there is a lot of variance with the average shareholding MLSOE not having evolved very far from an unreformed SOE but with some reformed MLSOEs such as CIMC, Lenovo, Huawei, and Haier appearing to be blazing new trails and registering large gains in performance. ${ }^{17}$

From the very start, the reform of state enterprises has been hamstrung by the social functions performed by SOEs for their workers. Comprising the core element of the urban labor force, a declining subset of the employees of the SOE sector rely on their work unit for housing, schooling, medical care, and pension benefits. Reforms that would rationalize the structure and employment of SOEs, focus their activities or force widespread closure of unviable enterprises have proven to be politically unpalatable because the social consequences—unemployment, loss of benefits—and the direct fiscal costs of compensating and/or retraining workers are high. ${ }^{18}$ Moreover, the state sector employees still wield considerable political clout and radical measures to terminate a longstanding social compact would be problematic socially as well as politically. Thus a slow phasing in of enterprise reforms, that whittles down state owned industry, has been supplemented by the attempts underway since the late 1980s to create a national pension system,

\footnotetext{
${ }^{17}$ The profit of CIMC increased by 120\% for the first 6 moths of 2005 compared to the same period a year ago (CIMC Semi-Annual Report 2005). Huawei’s profit increased 63\% from 2003 to 2004 (Huawei Techologies Annual Report 2004).

${ }^{18}$ Retraining, while it has helped some workers find employment mainly in urban services industries, often does not enable the displaced workers obtain jobs that pay as well as the ones lost.
} 
an affordable form of unemployment compensation, and state funded active labor market policies to train and place laid off workers. Once these have been implemented, the reform of the MLSOEs could proceed faster and more smoothly, possibly to full privatization of the majority of industrial firms.

Stitching together and adequately funding a national pension system from hundreds of provincial and municipal schemes has proven to be a much more difficult task than was imagined in the early 1990s. Until a solution is found, social security will continue to be shared with the enterprise sector albeit at great cost in the form of banking sector and fiscal resources used to shore up ailing SOEs.

Although the central government establishes the broad guidelines for the changes being introduced, much of the initiative and the responsibility for implementation rest with the urban centers. It is they also that stand to reap the benefit from success or pay the cost of industrial backwardness. Thus, the ongoing stage of China's reforms depends on the fruitful interaction between municipal authorities and firms, with the former attempting to create the conditions that will attract firms and result in a thriving economy while the latter seek to influence and benefit from municipal policies.

These then are the principal reforms that have brought the MLSOE sector to where it is today. Before we look more closely at the firms themselves, it is important to take full account of both the urban context in which reforms are unfolding and the contribution of the municipal governments to the business environment, the pace of enterprise reform and to the forces guiding organizational change. 


\section{Coordinating Urban with Industrial Change}

With urbanization accelerating, the role of China's cities in promoting industrial development is becoming even more critical. Cities provide the matrix of institutions and generate the localized knowledge spillovers that are valuable for businesses, but in China, the major urban centers are also positioned within certain limits to initiate reforms and to manage the implementation of ongoing industrial change. The substantial political powers vested in municipal authorities also means that they can take the lead in trying to build what Feldman and Martin (2004) call “jurisdictional advantage” and nudge the business community towards a supportive consensus. Jurisdictional advantage accrues from the unique assets that a particular location bestows on a firm. Many cities, especially coastal ones, have adopted such a proactive stance because they are recognizing that they must acquire differentiated industrial capabilities in order to sustain competitive advantage. Reliance on low production costs must now be superceded by an approach that is focused more on routinizing productivity gains and innovation in one or more industrial subsectors (Woetzel 2003). This can be a long drawn process and early movers that exercise good strategic foresight can acquire a commanding lead over other urban centers. The municipality can propose broad objectives or visions but it needs the support of the business sector to realize them. Cities better endowed with locational advantages, human capital, and financial institution, have an easier time in mobilizing the business community with incentives and through investment in the physical infrastructure and in institutions, but ultimately, it is the vitality of the business sector that is decisive. Whether it is the formation of clusters or the steady creation of high value-adding jobs, the actions of a multitude of firms reacting to municipal policies and through their own efforts at enhancing competitiveness by investing in 
skills, research, local universities, or the urban infrastructure that determine the scale of urban agglomeration benefits.

In this race to widen the margin of competitive advantage, the larger cities such as Shanghai and Guangzhou start with a number of advantages: they have a broader base of industries and such diversity promises larger urbanization economies; they have a broader revenue base and deeper banking and financial resources to support development; some of the ablest party cadres are appointed to manage these cities and through their networks they maintain close ties with the leading policymakers in Beijing, which gives them the latitude to pursue bolder reforms; and they are more attractive to foreign investors who are sensitive to the scale of agglomeration benefits and are seeking a vibrant urban environment that offers more varied lifestyle choices. These are not necessarily overwhelming advantages but when combined with geographical location and the benefits of an early start, they do favor the major cities in the Pearl River Delta region and the Yangtze Basin region. Shanghai and its surrounding cities not only have an edge in terms of scale, they also command a vast and increasingly affluent hinterland of close to 400 million people. But medium and smaller sized cities are competing fiercely and typically growing much faster than the larger cities because they are readier to absorb the influx of migrants from the countryside, ${ }^{19}$ because they enjoy cost advantages, and because they have the leverage that comes from localization economies.

What are the policy and reform options available to China's cities as they scramble to industrialize and how do these impinge upon the performance of the business sector? For most cities with industrial aspirations, the tendency is to use fiscal incentives and bank financing to promote industrial development and to buttress this with investment in physical infrastructure. Where there is an abundant local workforce or a ready supply of migrant workers, such an

\footnotetext{
${ }^{19}$ See Zhou and Cai (2005) for a discussion on migrants' lives in a new city.
} 
investment push - low cost strategy has frequently been sufficient to initiate an industrial spiral, especially in the medium and small cities and townships. However, for most of the larger cities, the stakes are much higher. Generic incentive mechanisms are no longer sufficient. ${ }^{20} \mathrm{~A}$ deepening of industrialization requires a much closer engagement between municipality and firms.

Cross-country and Chinese experience shows that industrial growth, productivity, and innovativeness as well as the formation of dynamic urban clusters is closely related to the ease with which new firms can enter an industry and on barriers to the exit of failing firms. Smaller firms are also responsible for the bulk of the employment generated in the urban economy. Hence, institutional conditions facilitating entry are among the most effective means for a municipality to induce industrial growth. By streamlining licensing and registration requirements, reducing regulatory impediments, improving access to financing and providing basic services with the minimum of red tape, one of the essential conditions for a thriving urban market economy can be met. A related requirement is the ease of exit because if failing firms are enabled to continue producing and investing, they divert resources from others and depress the profitability of viable firms. While in some cities such as Shenzhen and Hangzhou, the exit barrier is low, this remains a major problem in other Chinese cities and is related to enterprise reform that we will return to below (Dollar and others 2003). ${ }^{21}$

One of the main sources of agglomeration economies is the pool of skills available to firms in a metropolitan region. The volume, quality, and depth of skills hugely influences the productivity, and innovativeness of existing firms, the entry of new firms, and the overall

\footnotetext{
${ }^{20}$ A number of studies find that the correlation between the quantity of investment and economic growth is rather weak (Dollar and others 2003; Lin and Song 2002). Dollar and others (2003) find that the 23 Chinese cities they studied have built urban infrastructure to a point where shortages not longer constrain the performance of firms.

${ }^{21}$ Many cities suffer from excess capacity of 20 to $30 \%$ or more because of the lack of exits while Shenzhen and Hangzhou suffer much less with the excess capacity of 14 and 15\%, respectively (Dollar and others 2003).
} 
flexibility of the urban economy in particular its capacity to evolve in new directions to meet demand or acquire new clusters of activities. Cities like Beijing, Chongqing, Hangzhou, Guangzhou and Shanghai have an abundance of skills but firms in other cities cannot draw on a substantial local pool of skilled workers, resulting in sub par performance (Dollar and others 2003). Most municipalities recognize that to advance to a higher stage of industrialization, they must augment human resources if they have the financing to do so. This is no easy matter especially for the small and medium sized cities. Investing in universities and other training institutions is only a part of the process, a lot depends on how much the business sector is motivated to invest in formal and on-the-job training as well. There is, in addition, the problem of retaining workers and attracting workers from elsewhere. This depends on the institutions governing the supply and affordability of housing, ${ }^{22}$ the supply of municipal services, especially schooling, and the quality of the urban environment. ${ }^{23}$ In each of these areas, private providers have a role but in China, the dominant player is the municipal authority that spells out the ground rules and is directly or indirectly the source of a significant part of the financing. Cities like Shanghai, Beijing, Hangzhou, and others have a lead in this regard, but land use, financing, ${ }^{24}$ environmental quality and other issues relating to the integration of the national labor market continue to bedevil these and other cities whose future prospects depend upon the presence of a broad, constantly refreshed, and sound base of skills. ${ }^{25}$

\footnotetext{
${ }^{22}$ On the issue of housing for migrants, please see Wu and Rosenbaum (2005)..

${ }^{23}$ Crime is always high on the list of concerns for people in the larger urban centers. See Messner, Liu, and Karstedt (2005) for the recent trends in crime in urban China.

${ }^{24}$ Many cities have raised a large volume of funding by repossessing and rezoning surrounding agricultural land from farmers and allocating it for commercial, residential or industrial use. This provides a one time fiscal bonus but is not a device for meeting longer term fiscal requirements. Such encroachment also runs the risk of exacerbating urban sprawl and eating into the limited supply of arable land.

${ }^{25}$ Although Beijing, Guangzhou, and Shanghai do not face constraints in terms of supply of skills, performance of firms in these cities can be still greatly enhanced if labor markets are more flexible (Dollar and others 2003).
} 
A second factor that has contributed to knowledge spillovers is the investment in research and development (R\&D) and in technological extension services provided by firms. With the majority of China's research institutes still in the public sector and either reporting to municipal government or affiliated with SOEs, the municipality exercises substantial say in the level of research conducted (Son 2002). Coastal municipalities have taken a strong lead in attempting to both promote applied research and to push researchers to commercialize their findings by linking with business firms. Municipal bureaus such as in Shanghai have been especially aggressive in this regard, establishing stringent criteria to gauge the performance of universities and research institutes with respect to science and technology performance. This heightened pressure is a departure from past practice and it runs the risk of diverting too much energy away from teaching and basic research. One can also question the likely short-term gains in the form of useable research findings from a sudden ratcheting up of the effort to produce commercializable findings. Nevertheless, China's national and subnational governments are unequivocally committed to increasing the level and quality of $\mathrm{R} \& \mathrm{D}$ and are encouraging SOEs to view this as the means to long-term future competitiveness. What Baumol has called the "technology armsrace" is being embraced by Chinese cities in particular, the coastal cities most exposed to the competitive global economy (Baumol 2002).

Cities throughout China have wooed FDI as a means of mobilizing resources, modernizing industry and increasing exports. More recently, FDI has come to the viewed as one of the primary vehicles for raising industrial productivity and transferring technology aside from being often the only source of financing available to medium and small sized firms. Municipal governments of cities in Shanghai, Suzhou, Beijing, Dalian, Qingdao, Guangzhou, Hangzhou, and Shenzhen, for example, are eager to attract FDI in order to set up JVs with local firms or 
wholly-owned foreign subsidiaries that will advance the technological frontiers and through spillovers and demonstration effects contribute to business practices that will raise industrial productivity. ${ }^{26}$ Their success in achieving this is reflected in Figure 1. These cities are also using the opportunities presented by the large pool of knowledge workers coupled with other incentives to persuade MNCs to set up research laboratories in China. By 2004, nearly 400 foreign companies had invested in R\&D centers in China and while few companies have considered transferring core research function to China, ${ }^{27}$ they are helping to build a capability that is shaping the strategies of firms such as Huawei, Ningbo Bird, and Wanxiang, and will filter into other firms as well. Once again, while the policies of firms are decisive, municipalities play a major instrumental role in attracting FDI and are active in determining its composition with an eye to maximizing the knowledge spillovers.

\footnotetext{
${ }^{26}$ The demonstration effects from FDI seem to be rather strong in coastal cities, judging by the rapid increase in the external design patent applications (Cheung and Lin 2004).

${ }^{27}$ This reluctance arises from the current limits on research capacity in China and the perceived inadequacy of the protection for intellectual property.
} 
Figure 1: China's Top 10 Provincial Recipients in FDI

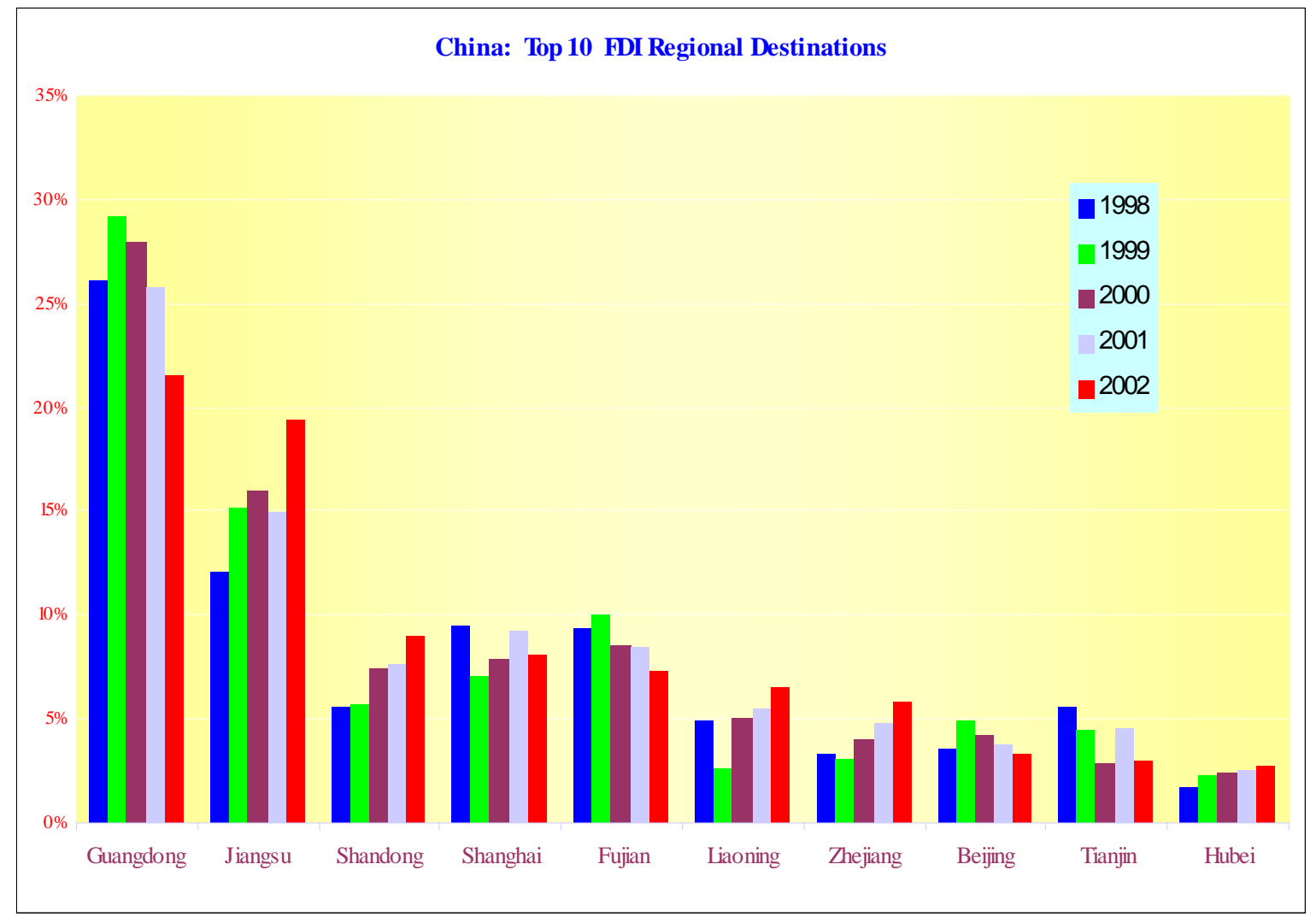

Source: China Statistical Yearbook (various years)

Building a municipal labor market that will be attractive for dynamic and well-managed firms requires close attention to the urban environment. This is also crucial for pulling in FDI into higher technology activities. The quality of the urban environment, the standard of services, and amenities provided and the level of housing facilities is a function of many factors.

Chief among them is administrative capacity and governance which remains variable throughout urban China and at the forefront of central government's attention. Several cities, especially in East Coast, have made concerted efforts to reduce red tape, to enhance transparency and to ease transaction costs for businesses by introducing electronic websites and permitting electronic processing of certain transactions (see Table 5). These changes are mirrored by the business climate in these cities and the entry of firms both local and foreign. 


\section{Table 5: Investment Climate Scores of 23 Cities in China}

\begin{tabular}{ll}
\multicolumn{3}{l}{ ICA } \\
City & Score \\
\cline { 1 - 1 } Hangzhou & A+ \\
Guangzhou A+ \\
Shanghai & A+ \\
Shenzhen & A+ \\
Chongqing & A \\
Changchun & A \\
Tianjin & A- \\
Dalian & A- \\
Beijing & A- \\
Zhengzhou A- \\
Wuhan & B+ \\
Nanchang & B+ \\
Xi'an & B+ \\
Changsha & B+ \\
Chengdu & B \\
Guiyang & B \\
Kunming & B \\
Nanning & B \\
Harbin & B- \\
Lanzhou & B- \\
\hline Source: Dollar and others (2003)
\end{tabular}

The efforts to reduce transaction costs are being buttressed by investment in infrastructure and housing. China’s municipalities are keenly aware that in the highly charged competitive environment, the quality of services provided by public utilities, urban transport, and the abundance of housing can tip the economic balance in the favor of one city over another. Hence, there is an ongoing infrastructure race as well. As we noted above, the leading cities are able to provide adequate level of infrastructure services for industry but in many instances, they still fall short of the standard achieved by the industrialized countries. The building of highly capital intensive physical infrastructure is hampered by the state of the capital markets and in particular by the thinness of structured bond markets that would permit cities to raise funds more 
efficiently and at lower cost for long lived projects. In the absence of such markets, the financing of infrastructure comes in the main from the banking sector and is distributed to contractors by local governments that are the principal borrowers. This privileges the more powerful and better connected governments in some of the major cities but it also increases the risks of banking resources being unwisely invested with the banking sector exercising little oversight on the use of the resources and being exposed to the risk of serious maturity mismatches (Honohan 2004). The full and efficient usage of the infrastructure already constructed is also an issue in many cities because of deficiencies in interagency coordination, regulatory practices and the pricing of services. Thus, sewerage facilities in several cities remain unused because no system is in place to adequately finance their operation, and the disposal of the rising solid waste is becoming a worsening burden as cities ran short of landfill sites. Similarly, the regulation of facilities in use remains uneven.

The lag in the development of institutions for long term financing is almost unavoidable because these markets need time to build up the matrix of skills, depth, experience, rules and credibility. The same can be said for local regulation. What the lag does though is to widen the advantages enjoyed by the major metropolitan governments. These are able to use their superior bargaining power to bid for the resources that are available in abundance and to invest in and operate urban infrastructure. Such investment has localized multiplier effects, stimulates growth, and pulls in other private investment as well. This is reflected in the performance of cities shown in Table 6. As is apparent, the large coastal cities in spite of their size have been able to sustain high growth rates throughout the 1990s not only because of industrial performance, FDI, the deepening of skills and the promoting of $R \& D$ but also because they have raised and ploughed in a vast amount of capital into infrastructure. 
Table 6: Per Capita GDP Growth and Investment Ratio of Selected Cities (1991-98)

\begin{tabular}{lrr} 
City & per capita GDP growth & Investment in GDP \\
\hline Beijing & 1.98 & 37.36 \\
Changchun & 13.68 & 25.07 \\
Changsha & 10.76 & 25.54 \\
Chengdu & 9.55 & 35.58 \\
Chongqing & 1.38 & 2.51 \\
Dalian & 10.03 & 25.11 \\
Guangzhou & 9.97 & 33.46 \\
Guiyang & 5.90 & 33.82 \\
Hangzhou & 10.18 & 23.52 \\
Harbin & 8.72 & 31.18 \\
Kunming & 11.73 & 26.07 \\
Lanzhou & 5.05 & 36.32 \\
Nanchang & 12.45 & 19.95 \\
Nanjing & 8.83 & 31.21 \\
Shanghai & 7.73 & 51.22 \\
Shenzhen & 9.12 & 31.53 \\
Tianjing & 8.18 & 39.60 \\
Wuhan & 9.18 & 38.88 \\
Xian & 8.73 & 26.36 \\
Zhengzhou & 10.51 & 37.13 \\
\hline
\end{tabular}

Source: Lin and Song (2002)

Improving the business environment is one major strand of the urban economic strategy in China. Equally important is the role of municipal and county governments in modulating and in implementing enterprise ownership reforms. Although the broad guidelines have been determined by the central government, the microstructure of the reforms and how these are being played out across urban China is in the hands of subnational governments. It is they that are setting the pace of privatization and it is the local industrial bureaus that determine how much autonomy is permitted to the corporatized state enterprises ${ }^{28}$ and the governance structures being crafted to monitor their performance. CIMC (and also Huawei) is one striking example of how the autonomy extended by the Shenzhen municipality has permitted the company's management to achieve dramatic results through horizontal mergers, innovation, and an aggressive strategy to

\footnotetext{
${ }^{28}$ Corporatized enterprises are those that have sold some of their equity to the non-state sector and have been organized as registered corporate entities with traded shares that are subject to the rules of corporate law.
} 
win local and foreign markets. TCL, ZTE, Haier, and Wanxiang are other examples of companies that have autonomy. But there are also numerous instances of municipal governments intervening to prop up failing enterprises, using their ownership clout to force companies to take over loss making entities, and micromanaging companies under their control, requiring them to maintain jobs and to "contribute" to municipal finances. Even for firms in the successful coastal cities, large gains in performance can be realized from more flexible labor markets, further privatization, and easier entry and exit of firms (Dollar and others 2003).

In short, the policy discretion enjoyed by municipalities in China’s decentralized economic system means that they have a large role in managing local industrial change and economic performance through enterprise reform, their management of the state enterprises, fiscal policy, access to bank financing, market regulation, and through their activities that impinge on the business climate. That still leaves a large and increasing responsibility for introducing organizational changes, devising strategy and conducting business in the hands of enterprises, which we will discuss below.

\section{From State-owned Enterprises to Modern Firms}

MLSOEs are spread across the spectrum performance-wise but somewhat more narrowly grouped with respect to structure and organizational dynamics. Below we will examine a number of attributes of MLSOEs with an emphasis on the trajectory of the members of what is likely to be the successful club.

Governance. Ownership and governance are the defining characteristics of enterprise reform in China and these are likely to be critical to future success. Starting from a condition of state ownership, plan-based production and control exercised through industrial ministries and 
bureaus, reform has created two classes of MLSOEs. One consists of wholly state-owned firms directed either by central ministries or more usually by provincial, municipal or county bureaus. While the formal structure of governance is usually well-defined, the actual degree of accountability varies by industrial sector, jurisdiction and bureaucratic entrepreneurship. Activist bureaus or bureaucrats being far more engaged and demanding than others. A second category of MLSOEs consists of enterprises that have been corporatized into limited liability corporations (LLC) and shareholding limited liability corporations (LLSC). Smaller SOEs were converted into LLCs and larger SOEs were commonly converted into LLSCs under the company law passed in 1994. They are accountable in principle to: the Board of Directors (BOD), a supervisory body, and a public agency responsible for the industry to which an enterprise belongs. The governance structure of the LLC is quite similar to a private company with a BOD providing oversight and day—to-day business conducted by a manager. The LLSC has similar governance structure to the LLC, but, the BOD for the LLSC has a stronger supervisory role than is the case for the LLC (Keister and Lu 2001). However, given the dominance of the government's share, government appointees on the Board and supervisory agencies provide the framework of accountability. Our research suggests that the formation of LLSCs does seem to have a large positive effect on performance, so that ownership reform is having predictable consequences with the change in governance contributing to the improvement. ${ }^{29}$ Nevertheless, findings from around the world and the Eastern European countries suggest that fully privatized firms are the ones that are the most efficient manufacturers. The ongoing ownership reform has introduced some elements of modern corporate governance into the SOE sector. The next stage

\footnotetext{
${ }^{29}$ Yusuf, Nabeshima, and Perkins (forthcoming) find that former SOEs reformed to becoming LLSCs perform the best, followed by joint venture firms. Although former SOEs reformed to become LLCs performed better than the non-reformed SOEs, the positive effect stemming from the ownership reform was much smaller than that for LLSCs and joint ventures.
} 
is full privatization and the transfer of the state's control rights in the majority of the MLSOEs so that firms can truly transform themselves and be able to compete against the global players.

Management. So long as MLSOEs were the production appendages of the command system, enterprise managers were responsible for meeting production targets and for the well being of their workforce. Professional management as practiced in the industrialized countries was unknown. This has begun to change as a result of privatization and the autonomy extended by subnational governments to the SOEs. A few of the larger and more outward oriented MLSOEs and those that have entered joint ventures with foreign firms, are setting the pace. Companies such as Haier, the Jialing Group, the Meidi Group, the Guomei Group, Founders, TCL, and CIMC have all sought to introduce new management techniques including matrix management (Hu and Bao 2003). Many MLSOEs have dynamic leaders who are successful production managers and are achieving good results. But managerial experience is still limited, with most companies lacking professional middle management appropriate for China’s circumstances and, in particular, equal to the challenge of globalization. ${ }^{30}$ Korea and other South East Asian economies, although ahead of China, have also been struggling to build management teams that can lead firms able to operate on an international scale. Developing manufacturing capability and achieving rapid export growth requires a narrower set of skills than does the management of large private or public limited companies with international operations. Only a tiny number of Chinese MLSOEs are at this stage. And building a stable of managers is the big challenge for the state sector but also for other kinds of firms.

Strategy. The expertise and orientation of state enterprise managers goes hand in hand with strategy-making skills that are adequate for single factory operations but not necessarily

\footnotetext{
${ }^{30}$ Although many private equity investors see great opportunities in China, especially for the emerging private firms, they are often confronted by the scarcity of managerial skills to build and sustain a successful business ("Milking It" 2004).
} 
commensurate for much larger, diversified operations encompassing the entire country and spreading to include foreign markets. With so many MLSOEs still strongly subject to state direction and having yet to build a pool of managerial skills, the ambition to frame a longer term strategy and the capability to chart the way forward and trace its key ramifications, is evident in only a few companies. Most still focus on production objectives and exports, and their implications for capacity as well as costs.

Structure. The vast majority of MLSOEs started out as single plant operations with a vertically integrated production system, little outsourcing and a comprehensive suite of internally provided services ranging from schooling to transport. Many still cling to this structure. The more dynamic firms, however, have acquired multiple plants—sometimes as a result of mergers forced upon them by the authorities. They have become allied with enterprise groups, ${ }^{31}$ and are divesting themselves of non-core operations, in some instances, to other members of the group, and outsourcing some of the services previously provided in-house. ${ }^{32}$ These trends are likely to continue as firms become more closely integrated with global production networks, are forced to compete with far more efficient foreign producers. But there are worrying signs that change is not necessary healthy. Deverticalization, outsourcing of non-core functions and greater focus on core specialization is the exception in even the leading Chinese firms. Haier and Lenovo have diversified into a wide array of business in order to repair eroding profit margins, dispersing managerial attention and diluting the brand name. By investing in commodified products where the profit margins are already thin, the leading manufacturers are not necessarily building corporate strength (Steinfeld 2004). In fact, the white (e.g. washers and dryers) and brown goods (e.g. TVs and sound systems) manufacturers are heading for a massive shakeout that could rock

\footnotetext{
${ }^{31}$ These 'jituan' were formed after December 1991 following a State Council Directive.

${ }^{32}$ In the case of FAW in Changchun, the SOE is also seeking to relocate some of its assembly operations to other parts of the country, including to Guangzhou.
} 
the manufacturing sector and the banking industry. The municipal governments are doing little to correct this tendency. Instead in their effort to promote industry and provide financing, they may be adding to excess growth in capacity and helping horizontal diversification to proceed, although this might be justified given the technological stage of China's development which forces firms to operate in markets for commodified products with narrow profit margins. ${ }^{33}$

Labor. Ever since the 1990s, MLSOEs have been attempting to reduce the tenured portion of their workforce with their high fixed costs in terms of social services and pension benefits. Most firms now rely more on contract workers and have flexibility in reassigning workers among activities, but some tenured staff remain and many firms continue supporting their pensioners. Promotion is still strongly determined by length of service rather than merit, the wage structure has only a modest slope, and bonuses continue to be relatively evenly shared. In other words, the internal reward system remains fairly egalitarian and career ladders favor seniority. Even with an increasing share of contract workers, political pressure can make it difficult for firms to lay off workers especially in the smaller cities where alternative employment options are few. This state of affairs is likely to be transformed by four developments. First is the greater integration of the domestic labor market as hukou restrictions are further eased. Second is the initiatives taken by the leading coastal cities to deepen and diversify the pool of skills which are viewed as fundamental to industrial dynamism and the vitality of clusters. Third are the measures being taken by firms and by municipalities to invest in training with the average manufacturing firm now budgeting for 20 hours per annum of training per worker. Fourth is the attention by firms such as the Meidi Group, the Wanke Group, and the Ping An Group to focus on human resources management recognizing that employee skills and commitment were the key to success through innovation (Hu and Bao 2003).

\footnotetext{
33 See Khanna and Palepu (2002).
} 
IT. Chinese joint venture firms that are linked to global production networks are adopting IT to conduct e-business, share knowledge within the firm and manage finances and outsourcing. These firms are moving to paperless online transactions, order fulfillment, tracking and invoicing. After a slow start, IT use is beginning to be assimilated by other enterprises including the MLSOEs. In 2004, for instance, the average enterprise was setting aside 5 percent of the value of sales for IT investment in hardware and skills. How soon this will begin to have an impact is hard to tell. But in time, the spread of IT, supported by municipal investments in hardware services access and pricing could accelerate changes in management, organizational structure, skill intensity of production, and innovativeness (OECD 2004). For the successful MLSOEs, this will be the direction for the future and it will have consequences for staffing, outsourcing, and efficiency.

Innovation. Over the past five years China has almost doubled her spending on R\&D to 1.6\% of GDP (2002). Among the MLSOEs large firms and joint ventures have taken the lead. Other firms invest little in research. Much of the research even by the bigger firms is of an applied nature to assure quality and to assimilate technologies. Very little is as yet leading to incremental process or product innovation, though in time that too will come if the investment in R\&D continues and the pool of skilled researchers expands.

In sum, the MLSOEs are undergoing a change in ownership and the broader governance structure. They have begun to modify management, strategy and the internal organization of the firm in response to the reform efforts of national and municipal governments, market pressures, and globalization. They are also moving towards multiplant operations, a degree of deverticalization of production and outsourcing of some services. The more dynamic among the MLSOEs are finding it expedient to make modifications. However, inertia, continued oversight 
and interference from supervisory agencies, and the soft budget constraints, undercut competitive pressures to streamline their activities and focus on core products.

These very same forces have also limited the degree to which the leading MLSOEs have engaged in global production networking and the use of IT to engage in e-business as well as to integrate with suppliers and buyers (Jefferson and Zhong 2004). Under competitive as well as government pressure, MLSOEs have stepped up R\&D and have absorbed many state-owned research centers, but typically it is of the listening-post kind or oriented towards adaptation of existing technologies from abroad. At best, the majority of the more successful MLSOEs are attempting to compete on the basis of price, delivery and to a lesser extent, quality. They are, in general, far from ready to compete as yet in terms of technology or in the vast majority of cases, to establish their own brand names outside of China.

This leaves a small number of MLSOEs that are engaged in flourishing joint ventures such as Shanghai Automotive. Through technology transfer these firms are often highly efficient producers that use IT competently and are conducting R\&D to utilize foreign technologies primarily for the domestic but also for global markets. They have borrowed certain elements of management and organizational structure from their foreign partners. But so far, it is difficult to identify MLSOEs which can be classified on the basis of organization, management expertise, organizational culture and production capability as the equal of major foreign MNCs.

\section{Creating a World Class Corporate System}

Observers of Chinese MLSOEs have remarked that China still lacks world-class industrial companies (Nolan 2000). With the exception of Haier and possibly Huawei and Lenovo, no Chinese industrial firm or enterprise group has the size, management skills, and the mix of capabilities to operate on a global scale. This is not surprising, because the MLSOEs are 
having to telescope in a few decades, managerial and organizational changes that occurred in the U.S. over more than a century. ${ }^{34}$ Undoubtedly, the ranks of the handful of leading firms will thicken and FDI will assist in the process, but much will depend on the future course of state ownership and the state's role in determining industrial organization and maintaining a soft budget constraint. International experience although grounded in a past and in institutions very different from those of China, does offer some guidance with respect to government policy towards industry. There is, in addition, a rich literature assessing the many kinds of business models being employed worldwide and the effectiveness of different types of business groups. From among these offerings, several merit attention by the Chinese.

\section{Other Business Models}

How can international experience inform the future interactions between Chinese municipalities and MLSOEs? The literature on urban economics and on urban geography shows that if the diseconomies of urban size can be controlled then scale promises large productivity gains via agglomeration effects. The average size of cities in China is below the optimum and the low Gini coefficient indicates the small number of very large urban areas. Thus, from the standpoint of economic advantage, there is potential for urban growth to be exploited. For instance, if a size of city is $50 \%$ below the optimum size, then doubling the city size can increase the value-added per worker by 35\% (see Table 7). But China's expanding cities will have to invest heavily in livability in order to continue attracting industry.

\footnotetext{
${ }^{34}$ Ferguson and Wascher (2004) note that before the Civil War in the U.S., most companies were sole proprietorships or partnerships, but this changed with advances in transport and communications and the growth of markets all of which favored larger hierarchical organizations. Further changes came in the wake of financial market developments, with multi-plant operations, and most recently, the advent of IT.
} 
Table 7: Gains from Moving to Optimum Size of City for Chinese Cities

\begin{tabular}{ccccc} 
& \multicolumn{4}{c}{$\%$ current size below optimum } \\
\cline { 2 - 5 } & 50 & 40 & 30 & 20 \\
\hline \% gain in VA per worker & $35.0 \%$ & $20.0 \%$ & $9.5 \%$ & $4.1 \%$ \\
\hline Source: Henderson (2004) & & & &
\end{tabular}

Livability depends on the quality of the physical infrastructure, social amenities, recreational facilities, and the environment. In many Chinese cities, these are barely adequate. In the face of continued migration and automobility, living condition could deteriorate in the absence of well planned investments and effective regulation. ${ }^{35}$

Cities must also work to enhance the competitiveness of the local economic environment so as to facilitate the entry and exit of firms. In this regard, their policies towards the SOEs will be important in two respects. First, the treatment of the SOEs will influence the rules governing market competition more broadly. Second, it would determine how quickly and in what manner SOEs embark on a reform of their governance structure and operations. It is becoming clear that industrial policies that rely on directed credit, subsidies, trade barriers and government purchases of products to induce the development of targeted industries, are frequently a costly and ineffective approach to local industrialization. Moreover, many of the instruments used in support of such policies are now disallowed by the WTO. Government efforts to impose mergers and to create enterprise groups have not yielded robust results anywhere in East Asia. They can burden successful firms with unwanted baggage rather than creating larger and more dynamic entities. It is much better to let market forces do their job, and manage development with the help of a sound competition policy.

\footnotetext{
${ }^{35}$ As migration increases, authorities will need to pay closer attention to the risks from infectious diseases such as HIV and sexually-transmitted disease (Smith and Hugo 2005).
} 
Privatization of industrial enterprises has been shown to raise productivity and lead to positive business outcomes in the vast majority of cases. ${ }^{36}$ Furthermore, there is little evidence from other transition economies to suggest that a gradual and elaborately sequenced ownership reform has advantages over a swifter form of privatization. ${ }^{37}$ Evidence from large successful cities point to the further gain that can be realized through ownership reform which will lead to more flexible labor market and ease of entry and exits (Dollar and others 2003).

Basic research, promoting R\&D in frontier technologies in promising areas, and providing manufacturing extension services may require investment by the municipalities and incentives for companies. There is a strategic role here for the local governments and some Chinese cities have been instrumental in raising R\&D to high levels. For example, Beijing now spends $7 \%$ of its GDP on R\&D and Shanghai over 2\% as against 1.34\% by Singapore ("Hong Kong Pays" 2004). But companies must also perceive the competitive advantage of technology development or else the state will be pushing on a string.

All companies can derive valuable lessons from carefully studying their current and potential competitors--domestic and foreign, and not just the successful ones only but also those that have shown promise and then failed.

There can be no denying that the contribution of professional management and strategy making to the competitiveness, growth, and profitability of firms. A small number of Chinese MLSOEs have the leadership but few have as yet equipped themselves with the other attributes. The absence of managerial depth also shows up in the structure of MLSOEs. While the trend worldwide is towards flatter hierarchies, large firms with national or international operations

\footnotetext{
${ }^{36}$ See the reviews by Djankov and Murrell (2002) and Megginson and Netter (2001)

${ }^{37}$ Both Balcerowicz (2003) and Havrylyshyn (2004) note that fast reformers on balance registered somewhat better performance overall during 1990s. Slow reformers have often become bogged down, China included, with new reforms being opposed by strongly entrenched vested interests.
} 
must have the organizational resources and managerial hierarchies to deal with complex and widely ramified operations. Privatization can contribute to the strengthening of management and subnational governments can provide an added push by ensuring that the institutions of corporate governance enforce the needed discipline.

As we noted above, the quality of corporate governance is associated with the performance of firms. Following a spate of scandals, the international business community is coming to recognize that the meaningfulness of corporate governance depends on the composition, chairmanship, independence, and specific functions of the board of directors, so as to provide oversight on strategy, accounting practices, and auditing standards. So far, even reformed MLSOEs are subject to weak and idiosyncratic governance and thus much ground must be covered to approach international best practice by regulators, who need to develop and enforce institutions, and by firms that need to acknowledge and work with the new rules.

Competitive and rapidly growing firms that invest in R\&D encourage different forms of innovation. Municipal agencies can support this tendency by making it easier for firms to enter into joint research ventures and to contract with universities and research institutes. These are practices infrequently adopted by MLSOEs so far. Competing on the basis of technology will become necessary once companies are fully exposed to market pressures and seek to expand overseas.

The leading MLSOEs have begun adopting stronger incentive regimes appropriate for the market environment and with the encouragement of municipal authorities, they are giving more attention to enhancing their human resources, but not enough is known about training practices, pay scales, promotion ladders, and bonus schemes to assess the adequacy of the systems now in place. Similarly, the current composition of the internal labor markets and hiring policies of 
firms are uncertain. However, future competitiveness of firms will be increasingly tied to the upgrading of the workforce which will require the concerted efforts of firms and of the municipalities as well, which have a big stake in raising the level of skills.

While the internal workings of a firm are certainly key, as MLSOEs deverticalize and outsource, their competitiveness also depends on the efficacy of their cooperative arrangement with partners, suppliers, providers of business services, and buyers. Whether one considers Japanese keiretsu, Korean chaebol, American auto companies or the leading manufacturers of electronics, garments and machinery, the best firms are ones that have a clear strategy and based on this, have created a support system that leverages the resources, technologies, and innovativeness of others. There is no single best practice but plenty of good models. The vertically integrated and insular MLSOE does not approximate any of these models, nor do the loosely knit enterprise groups created by governmental fiat. If international experience is a guide, building international production networks and alliances to conduct research or product development will be necessary for the growth of MLSOEs that eventually graduate into the ranks of successful private sector firms.

Finally, as the Chinese economy becomes more integrated domestically and closely linked with the global market, it will be harder to preserve or create sheltered domestic niches. Manufacturing firms across the world are finding that, little by little, local markets are becoming coextensive with global markets as trade barriers recede, transport charges fall, and the Internet enormously enhances the availability of information and cuts down transaction costs. In this kind of environment, survival is coming to depend upon preparedness and flexibility. Much more so than in the past, strategy and innovativeness matters. And also location matters. The 
ably managed and innovative firms will grow and agglomeration economies can be the springboard to their success. 
Reference List

Andors, Stephen 1977. China's Industrial Revolution. New York: Pantheon Books.

Appleton, Simon and Lina Song. 2005. "The Myth of the 'New Urban Poverty'? Trends in Urban Poverty in China, 1988-2002." Presented at Urban China in Transition, New Orleans, Louisiana, January 15, 2005.

Balcerowicz, Leszek. 11-18-2003. "Post-Communist Transition in a Comparative Perspective." Presented at Practitioners of Development Seminar Series, Washington, DC, November 18, 2003.

Baumol, William J. 2002. The Free Market Innovation Machine. Princeton: Princeton University Press.

Cheung, Kui-yin and Ping Lin. 2004. "Spillover Effects of FDI on Innovation in China: Evidence From the Provincial Data." China Economic Review 15(1): 25-44.

Chow, Gregory 1985. The Chinese Economy. New York: Harper and Row Publishers.

Djankov, Simeon and Peter Murrell. 2002. "Enterprise Restructuring in Transition: A Quantitative Survey." Journal of Economic Literature 40(3): 739-792.

Dollar, David, Shi, Anqing, Wang, Shuilin, Xu, Lixin Colin. 2003. Improving City Competitiveness Through the Investment Climate: Ranking 23 Chinese Cities Washington, DC: World Bank.

Duckett, Jane 1998. The Entrepreneurial State in China: Real Estate and Commerce Departments in Reform Era Tianjin. London: Routledge.

Fan, C. Cindy. 2004. "Migration in China: A Review of Recent Findings and Policy Recommendations." Prepared for the 11th Five Year Plan of China. Washington, DC: World Bank.

Feldman, Maryann and Roger Martin. 2004. "Jurisdictional Advantage." NBER Working Paper 10802. Cambridge, Mass.: National Bureau of Economic Research.

Ferguson, Roger W. Jr. and William L. Wascher. 2004. "Lessons From Past Productivity Booms." Journal of Economic Perspectives 18(2): 3-28.

Gore, Lance L. P. 1998. Market Communism: The Institutional Foundation of China's Post-Mao Hyper-Growth. Hong Kong: Oxford University Press. 
Havrylyshyn, Oleh. 2004. "Avoid Hubris but Acknowledge Successes: Lessons From the

Postcommunist Transition." Finance and Development(September 2004): 38-41.

Henderson, J. Vernon. 2004. "Issues Concerning Urbanization in China." Prepared for the 11th

Five Year Plan of China. Washington, DC: World Bank.

"Hong Kong Pays More Attention to Tech" 2004. Asian Wall Street Journal. October 27.

Honohan, Patrick. 2004. "Finance in China: Removing Ambiguity Over Government's Role."

Paper prepared for the Report on 11th Five Year Plan. Washington, DC: World Bank.

Howell, Jude 1993. China Opens Its Doors. Colorado: Lynne Rienner Publisher's Inc.

Hu, Zhigang and Xiowen Bao 2003. Classic Managing Models for China's Top Enterprises.

Beijing: Central Compilation \& Translation Press.

Hutchings, Graham 2001. Modern China: A Guide to A Century of Change. Cambridge, Massachusetts: Harvard University Press.

Jefferson, Gary H. and Kaifeng Zhong. 2004. "An Investigation of Firm-Level R\&D Capabilities in East Asia," in Yusuf, Shahid, Kaoru Nabeshima, and M. Anjum Altaf (eds.), Global Production Networking and Technological Change in East Asia. New York: Oxford University Press.

Keister, Lisa A. and Jin Lu. 2001. "The Transformation Countries: The Status of Chinese StateOwned Enterprises at the Start of Millennium." NBR Analysis 12(3): 5-31.

Khanna, Tarun and Krishna Palepu. 2002. "Emerging Giants: Building World-Class Companies in Emerging Markets." Harvard Business Review(October).

Lardy, Nicholas R. 1992. Foreign Trade and Economic Reform in 1978-1990. Cambridge, U.K.: Cambridge University Press.

----- 2002. Integrating China into the Global Economy. Washington, DC: Brookings Institute.

Liang, Zai, Hy Van Luong, and Yiu Por Chen. 2005. "Urbanization in China in the 1990s: Patterns and Regional Variations." Presented at Urban China in Transition, New Orleans, Louisiana, January 15, 2005.

Lin, Justin Yifu and Zhiqiang Liu. 2000. "Fiscal Decentralization and Economic Growth in China." Economic Development and Cultural Change 49(1): 1-21.

Lin, Shuanglin and Shunfeng Song. 2002. "Urban Economic Growth in China: Theory and Evidence." Urban Studies 39(12): 2251-2266. 
Megginson, William L. and Jeffery M. Netter. 2001. "From State to Market: A Survey of

Empirical Studies on Privatization." Journal of Economic Literature 39(2): 321-389.

Messner, Steven F., Jianhong Liu, and Susanne Karstedt. 2005. "Economic Reform and Crime in Contemporary China: Paradoxes of a Planned Transition." Presented at Urban China in Transition, New Orleans, Louisiana, January 15, 2005.

"Milking It" 2004. The Economist. October 7.

Naughton, Barry. 1988. "The Third Front: Defense Industrialization in the Chinese Interior." China Quarterly 115 351-386.

----- 1996. Growing Out of the Plan. New York: Cambridge University Press.

OECD 2004. Understanding Economic Growth. Paris: OECD.

Oi, Jean Chun 1999. Rural China Takes Off: Institutional Foundations of Economic Reform.

Berkeley, CA: University of California Press.

Perkins, Dwight H. and Shahid Yusuf 1984. Rural Development in China. Baltimore, MD: Johns Hopkins University Press.

Putterman, Louis and Xiao-yuan Dong. 2000. "China's State-Owned Enterprises." Modern China 26(4): 403-447.

Richman, Barry M. 1969. Industrial Society in Communist China. New York: Vintage Press.

Riskin, Carl 1987. China's Political Economy. New York: Oxford University Press.

Steinfeld, Edward S. 2004. "Chinese Enterprise Development and the Challenge of Global Integration," in Yusuf, Shahid, Kaoru Nabeshima, and M. Anjum Altaf (eds.), Global Production Networking and Technological Change in East Asia. New York: Oxford University Press.

Wheelwright, E. L. and Bruce McFarlane 1970. The Chinese Road to Socialism. New York: Monthly Review Press.

Woetzel, Jonathan R. 2003. Capitalist China: Strategies for a Revolutionized Economy. Singapore: John Wiley \& Sons (Asia).

Wu, Weiping 1999. Pioneering Economic Reform in China's Special Economic Zones. Aldershot, U.K.: Ashgate Publishing.

Wu, Weiping and Emily Rosenbaum. 2005. "Migration and Housing: Comparing China With the United States." Presented at Urban China in Transition, New Orleans, Louisiana, January 15, 2005. 
Yusuf, Shahid, Kaoru Nabeshima, and Dwight H. Perkins. 2004. "Under New Ownership: Privatizing China's State-Owned Enterprises.".Forthcoming.

Zhou, Min and Guoxuan Cai. 2005. "Trapped in Neglected Corners of a Booming Metropolis: Patterns of Residence and Adaptation Among Migrant Workers in Guangzhou." Presented at Urban China in Transition, New Orleans, Louisiana, January 15, 2005. 